\title{
Damar İçi Stentlerde Malzeme Seçiminin ve Tasarımının Restenoz ve Diğer Stent Kaynaklı Problemlere Etkileri, Stentlerin Ekonomideki Yeri (Bir Genel Derleme)*
}

\author{
Gülşen Akdoğan ${ }^{1 * *}$, Ömer Burak İstanbullu² \\ ${ }^{1}$ Erciyes Üniversitesi, Mühendislik Fakültesi, Biyomedikal Mühendisliği Bölümü, Kayseri, Türkiye (ORCID: 0000-0001-6473-8897) \\ ${ }^{2}$ Erciyes Üniversitesi, Mühendislik Fakültesi, Biyomedikal Mühendisliği Bölümü, Kayseri, Türkiye (ORCID: 0000-0003-3150-9195)
}

(Konferans Tarihi: 5-7 Mart 2020)

(DOI: 10.31590/ejosat.araconf26)

\begin{abstract}
ATIF/REFERENCE: Akdoğan, G. \& İstanbullu, Ö. B. (2020). Damar İçi Stentlerde Malzeme Seçiminin ve Tasarımının Restenoz ve Diğer Stent Kaynaklı Problemlere Etkileri, Stentlerin Ekonomideki Yeri (Bir Genel Derleme). Avrupa Bilim ve Teknoloji Dergisi, (Özel Sayı), 204-215.
\end{abstract}

\section{$\ddot{O} \mathbf{z}$}

Damar yolu hastalıklarının tedavisinde kullanılan damar içi stentler, özellikle kardiyovasküler cerrahi alanında hayat kurtarıcı tedavi olarak önemli bir rol oynamaktadır. Stentlerin tasarımı ve üretiminde kullanılan malzemeler; operasyonel uygulama ve damar yolu tıkanıklıklarına çözüm sunma açısından oldukça etkilidir. İlk stent tasarımları 316L (düşük karbonlu medikal paslanmaz çelik) malzemelerin kullanıldığı kaplamasız metal stentler şeklinde geliştirilmiş ve günümüzde şekil hafizalı akıllı stent tasarımları, ilaç salınımlı stent teknolojileri ve biyobozunur stentler ortaya çıkmıştır. Yeni teknoloji stentlerin üretiminde polimerik malzemelerin yanı sıra nitinol, Ti alaşımları ve Mg tabanlı malzemeler öne çıksa da günümüzde halen 316L malzeme kullanılarak üretilen stentler de mevcuttur.

Korozif bir ortam olan damar yolu içerisine yerleştirilen kaplamasız metal stentlerde korozyon meydana gelmesi sonucunda stentin mekanik mukavemeti zayıflamakta ve bu da stentin kırılmasına yol açarak vasküler yolun tekrar tıkanmasına neden olabilmektedir. İlaç salınımlı stentlerde ise kullanılan antiproliferatif ajanların zamanla tükenmesi neticesinde stent kaynaklı tıkanma problemleri ile karşılaşılmaktadır. Biyobozunur stentlerde ise stentin bozunma süresinin kontrol altına alınması, çözüm bekleyen bir başka problemdir.

Vücut içerisine yerleştirilen stentlerde; üretimlerinde kullanılan malzeme fark etmeksizin, vücut sıvıları ile sürekli olan etkileşimleri sonucunda, zamanla tekrar damar tıkanıklı̆ğna yol açan problemler meydana gelmektedir. Dolayısıyla mevcut tüm stentlerin damar yolu hastalıklarına yalnızca geçici bir tedavi sağlayabildiği göze çarpmaktadır.

Stentlerin sunduğu tedavinin kalıcı olabilmesi için stent içi restenozun (yeniden tıkanma) giderilmesine yönelik çalışmalara büyük ölçüde ihtiyaç duyulmaktadır. Stent üretimi ve tasarımına yönelik güncel AR-GE çalışmaları bu doğrultuda ilerlemektedir. Bu derleme makalede, damar içi stentlerin gelişimi sürecinde ortaya çıkan farklı malzemelerden üretilmiş tasarımlar irdelenmektedir. Günümüzde klinik uygulamalarda kullanılan tüm stent gruplarında ortak olarak karşılaşılan restenoz problemine; stentin yüzey yapısının iyileştirilmesi yöntemleri ile çözüm sunulan yeni çalışmalar ortaya konulmaktadır.

Anahtar Kelimeler: Damar içi stentler, Damar yolu tıkanıklığı, Biyomalzemeler, Restenoz, Stent trombozu, Stent korozyonu

\footnotetext{
* Bu makale International Conference on Access to Recent Advances in Engineering and Digitalization (ARACONF 2020) de sunulmuştur.

** Erciyes Üniversitesi, Mühendislik Fakültesi, Biyomedikal Mühendisliği Bölümü, Kayseri, Türkiye ORCID: 0000-0001-6473-8897, akdogang@erciyes.edu.tr
} 


\title{
Effects of Material Selection and Design on Restenosis and Other Stent Based Problems in Intravascular Stents, The Situation of Stents in the Economy (A Review)
}

\begin{abstract}
Intravascular stents used in the treatment of vascular diseases play an important role as a life-saving treatment especially in the field of cardiovascular surgery. Materials used in the design and manufacture of stents are very effective in terms of operational application and treatment of vascular occlusion. The first stent designs were developed in the form of bare metal stents using 316L (low carbon medical stainless steel) materials, and today, shape memory stent designs, drug eluting stent technologies and biodegradable stents have emerged. In addition to polymeric materials, nitinol, Ti alloys and Mg-based materials stand out in the production of new technology stents, there are still stents produced using 316L material today.

For bare metal stents placed in the vessel which is a corrosive environment, the mechanical strength of the stent weakens as a result of corrosion which may lead to breaking of the stent that result in blockage of the vascular pathway again. In drug eluting stents, as a result of the depletion of antiproliferative agents with time, stent-induced occlusion problems are encountered. In biodegradable stents, controlling the degradation duration of the stent is another problem that is waiting for a solution.

As a result of the continuous interaction of stents with body fluids, problems causing vascular occlusion occur over time in the stents which are placed inside the body regardless of the materials used in their production. Therefore, it is remarkable that all existing stent designs can only provide a temporary treatment to vascular diseases.

Researches which are aimed to overcome in-stent restenosis (re-occlusion) are highly necessary for making stent treatment to be permanent. Current R\&D studies for stent production and design are progressing in this direction. In this review article, designs produced using various materials arising during the development of intravenous stents are examined. New studies that offer a solution to restenosis which is the common problem in all stent groups used in clinical practice today by using the techniques of improvement of the stent surface structure are presented.
\end{abstract}

Keywords: Intravascular stents, Vascular occlusion, Biomaterials, Restenosis, Stent thrombosis, Stent corrosion

\section{Giriş}

Kardiyovasküler hastalıklar başta olmak üzere kalp, beyin ve böbrek yollarındaki damarların tıkanması ile sonuçlanan tüm rahatsızlıklar; ölüm riski oldukça yüksek olan hastalıklar grubuna girmektedirler. Bu hastalıklar girişimsel ve girişimsel olmayan yöntemler ile tedavi edilmeye çalıșlmaktadır [1]. Biyomedikal cihazlar ve biyomalzeme teknolojilerindeki ilerlemeler sayesinde, özellikle son yıllarda kardiyovasküler uygulamalarda önemli gelişmeler yaşanmıştır. Damar yolu hastalıklarının tedavi edilmesi amacıyla damar içi stentler geliştirilerek üretilmiş ve kullanılmıştır. Stent, damar tıkanıklığı tedavisinde kullanılan, metal veya polimerden yapılmış esnek bir kafes-boru şeklindeki yapıdır [2].

Vücut içerisindeki farklı kullanım bölgelerine göre tasarlanan stentlerin yapısı hem malzeme içeriği bakımından hem de tasarım açısından değişiklik göstermektedir. Bu amaç için çeşitli stent tasarımları ortaya çıkmıştır. İlk kardiyovasküler stent uygulaması 1986'da paslanmaz çelik bir stent (Wallstent, Schneider AG) kullanılarak yapılmıştır [3]. Bu stent gruplarında karşılaşılan klinik uygulama zorlukları, kırılma ve korozyon gibi mekanik problemler ve uzun vadede yaşanan restenoz gibi damar tıkanıklığı problemlerinin üstesinden gelmek için, farklı malzemeler kullanılarak üretilen stentler ortaya çıkmıştır [4]. 1987'de ilk FDA onaylı stent (Palmaz-Schatz, Johnson\&Johnson) geliştirilmiştir. 1990'lar in başında geliştirilen diğer stent tasarımları (Flexstent, Cook; Wiktor, Medtronic; Micro, Applied Vascular Engineering; Cordis, Cordis; Multi-link, Advanced Cardiovascular Systems) elastik toparlanma ve restenoz problemleri riskini azaltabilmiştir [5]. Daha sonraki yıllarda da, biyouyumlu metallerde korozif vücut sıvıları içerisinde iken yaşanan korozyon problemlerinin çözümü için kaplamalı metal stentler yaygınlaşmıştır [6].

Kalıcı özellikteki kaplamasız metal stentler; vücut içerisinde zamanla komplikasyona neden olabilmektedir [7]. Vücut sıvıları ve dokularının stent malzemesi ile etkileşimi sonucunda stent yüzeyinde zaman içerisinde madde tutunumu artmakta veya stent çevresinde yeni hücrelerin oluşumu ve birikimi meydana gelmektedir [8]. Neticede bu etkileşim; tıkanıklığı stent kullanılarak tedavi edilen bir damar yolunda, ilerleyen zamanlarda tekrar tıkanma meydana getirmektedir. Bu durum ayrıca kanın damar içerisindeki akış hızını ve damar çeperine yaptığı basıncı da etkileyerek düzensiz yol almasını beraberinde getirmektedir [9], [10].

Biyobozunur malzeme teknolojisindeki ilerlemeler neticesinde geliștirilen ilaç salınımlı stent (ISS) ve tamamen biyobozunur stent teknolojileri ile damar içi stentlerde yaşanan geç dönem tıkanma riski çözülmeye çalışılmaktadır. İSS'ler, etrafina yaydığı kimyasal madde sayesinde stent ile malzeme etkileşimi sonucunda yüzeyde madde tutunumunu ve hücre birikimini azaltmaktadır. Bu tip stentler; ilaç salınım döneminde yeniden tıkanma riskini düşürmüş olsa da ilaç salınımı bittikten sonra ilaçsız stent grupları ile aynı özelliğe dönüşmekte ve daha yüksek riskte yeniden tıkanmaya sebep olmaktadırlar. Dolayısıyla İSS teknolojisi, stent kaynaklı damar yolu tıkanıklı̆̆ı için kalıcı bir çözüm sunamamakla birlikte hastalı̆̆ı erteleyici bir rol üstlenmektedir. Günümüzde kullanılan tüm damar içi stentler damar yolu tıkanıklıklarına sadece geçici bir çözüm sunabilmektedirler [11], [12]. Tamamen biyobozunur stentler ise henüz klinik uygulamalarda yaygın bir kullanım alanı bulamamıştır. Bu stentlerde erken bozunma problemleri ve kalın örgüleri nedeniyle damar içerisine yerleştirme problemleri üzerinde ar-ge çalışmaları devam etmektedir [13], [14], [15]. Kalıcı stentlerin 
tamamında görülen geç dönem stent içi tıkanma problemi halen çözüm beklemeye devam etmektedir. Stent üretiminde kullanılan malzemelerin yüzeyine madde tutunamama fonksiyonu kazandırılması ile bu probleme kalıcı bir çözüm sunulabilir.

\section{Materyal ve Metot}

\subsection{Stent Teknolojileri}

Koroner damar hastalıklarının getireceği zararların azaltılması için ilk etapta balon uygulaması ile damar genişletme yoluna gidilmiş olsa da bu yöntemin kalıcı bir etkiye sahip olmadığı görülmüştür. İlk geliş̧irilen metal stent teknolojisi sayesinde damar yolu tıkanıklığını gidermek için kalıcı bir destek yapısının kullanılabilirliği görülmüş̧ür.

Kaplamasız metal stentler, ilaç salınımlı stentler ve biyobozunur stentlerden hangisinin tercih edileceği, hastanın durumuna ve stent uygulanacak damar bölgesine göre belirlenmektedir.

Şekil-1'de gösterildiği gibi, bir damar içi stent uygulamasında, hastalıklı damara normal bir damar yolundan ince bir kılavuz tel aracılı̆̆ ile ulaşılır. Hastalığın oluştuğu bölgeye kılavuz tel vasıtasıyla balon veya stent yerleştirilir. Darlık ya da tıkanıklığın olduğu bölgeye yerleştirilmeden önce kapalı olan stentin, dışarıya uzanan mekanizması çekilerek açılması ve damar çeperine yerleştirilmesi sağlanır. Darlık açıldıktan sonra kılavuz tel dışarı çıkarılır [16].
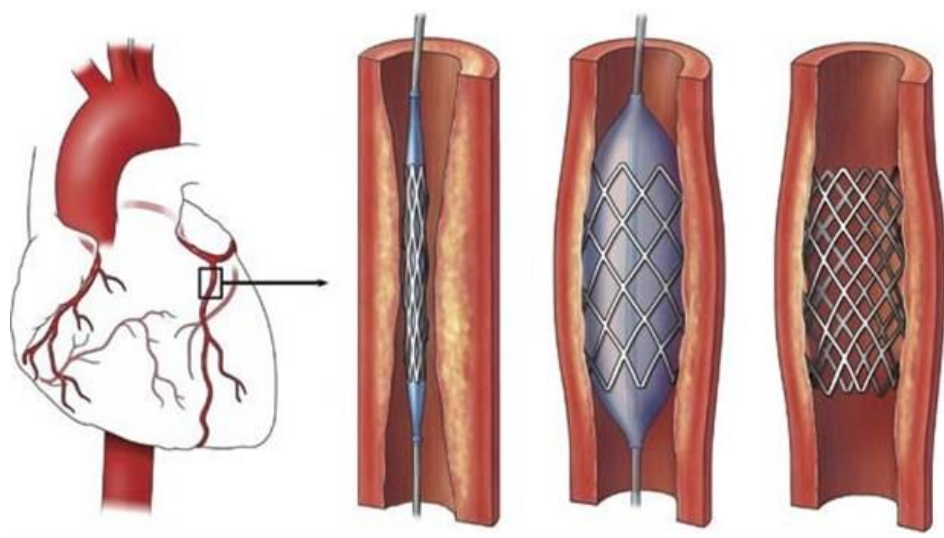

Şekil-1: Daralan bir damara uygulanan stent

Farklı ihtiyaçlara göre farklı boyutlarda metal veya polimer türlerinden farklı malzemeler kullanılarak üretilen stentler, genellikle 2-4 mm çap ve 10-30 mm uzunluklarda olurlar. Stentler, açılıp kullanılmadan önce, 1-2 mm genişlikteki sönük bir balonun üzerine büzülmüş vaziyette yer alırlar.

\subsubsection{Kaplamasız Metal Stentler}

Stentin uygulanacağı bölgedeki ihtiyaca göre, farklı malzemeler ve çeşitli tasarımlar kullanılmaktadır. Tıkanmış bir kan damarındaki akışı sağlamak için bölgede kullanılan malzeme esnetilebilir ve genişletilebilir özellikte olmalıdır [17], [18]. Kalıcı stent uygulamaları için malzemenin elastikiyet veya esnekliğine ek olarak, elastik geri toparlanma direnci, mukavemeti, mekanik ve kimyasal aşınma direnci önem taşımaktadır. Günümüzde halen kardiyovasküler stent üretiminde kullanılan biyouyumlu metaller bu özellikleri kısmen karşılayabilmektedir.

Kaplamasız metal stentler, taban malzemesini düşük karbon alaşımlı medikal paslanmaz çelik, kobalt-krom alaşımı malzeme, titanyum alaşımları ve şekil hafızalı akıllı malzemeler (Ni-Ti alaşımları) gibi biyouyumlu metallerin oluşturduğu ve vücut sıvıları ile metal yüzeyinin doğrudan temas halinde olduğu stentlerdir. Bu stentlerde kullanılan metalik malzemelerin çeşitliliği, her birinin mekanik ve fiziksel özelliklerinin birbirinden farklı olmasını beraberinde getirmektedir [19]-[21].

İlk stentlerin üretiminde kullanılan metal malzemelerde yaşanan mekanik mukavemetin düşük olması, elastik geri toparlanma durumu ve korozyon gibi sorunlar; stent üretiminde yeni malzemelerin geliştirilmesi ihtiyacını doğurmuştur. Bunun için düşük karbon alaşımlı medikal paslanmaz çelik, kobalt-krom alaşımı ve daha sonraları titanyum alaşımı malzemeler kullanılmıştır [22], [23].

Şekil hafizalı nitinol tabanlı stentlerin süper elastik yapısı ve elastik toparlanma direncinin düşük olması öne çıkarken 316L medikal paslanmaz çelikte ve kobalt krom alaşımlarında ise mekanik dayanımın yanı sıra düşük korozyon direnci önemli bir avantaj olmaktadır [24]. Vücut içerisinde uygulama kolaylığı için daha ince ve küçük yapıdaki stentlerin üretiminde bu malzemelerin kullanılması, daha dayanıkı bir ürün elde edilmesini sağlamaktadır [25]. Ancak 316L ve kobalt krom alaşımından üretilen stentlerde Manyetik Rezonans Görüntüleme (MRG) ve Radyografide uyumsuzluk problemlerini beraberinde getirmektedir [26]. Titanyum alaşımı malzemelerde ise düşük korozyon direnci, yüksek mekanik mukavemet ve biyouyumluluk problemlerinin olmamasının yanı sıra medikal görüntüleme cihazlarında kullanımında herhangi bir sınırlama bulunmaması, bu malzemelerin yaygınlaşmasını sağlamıştır [27], [28]. Tablo-1'de bu malzemelerin temel mekanik özellikleri gösterilmektedir. 
Tablo-1: Stent üretiminde kullanılan metallerin temel mekanik özellikleri

\begin{tabular}{|c|c|c|c|c|c|c|}
\hline Malzeme & $\begin{array}{c}\mathbf{T}_{\mathbf{E}} \\
\left({ }^{\circ} \mathbf{C}\right)\end{array}$ & $\begin{array}{c}\text { Young } \\
\text { Modülü } \\
(\mathbf{G P a})\end{array}$ & $\begin{array}{r}\text { Çekme } \\
\text { Dayanımı } \\
\text { (Mpa) }\end{array}$ & $\begin{array}{r}\text { Akma } \\
\text { Dayanımı } \\
(\mathrm{MPa})\end{array}$ & $\begin{array}{c}\text { Kırılma } \\
\text { Uzaması } \\
(\%)\end{array}$ & $\begin{array}{c}\text { Yoğunluk } \\
\left(\mathrm{g} / \mathrm{cm}^{3}\right)\end{array}$ \\
\hline $316 \mathrm{~L}$ & 1390 & 193 & 668 & 310 & 40 & 8 \\
\hline CoCr Alaşımı & 1454 & 210 & 960 & 560 & 20 & 10 \\
\hline Nitinol & 1310 & 83 & 895 & 690 & 50 & 6.45 \\
\hline Ti Alasımı & 1660 & 110 & 950 & 786 & 14 & 4.429 \\
\hline
\end{tabular}

Tablo-1'den anlaşılacağı üzere, metallerin mekanik özelliklerinde görülen farklılık, bu malzemelerden üretilen stentlerin de farklı davranışlara sahip olmasını beraberinde getirmektedir. 316L gibi demir esaslı alaşımlarda; uzun süreli kullanımlardaki korozif direncin zayıflamasından ötürü bozulmaların meydana geldiği gözlemlenmiştir [29], [30]. Kobalt-krom alaşımı malzemelerden üretilen stentlerde korozyon direncinin ve çekme dayanımının artırıldığı ve vücut ortamında iken 316L stentlere göre daha dayanıklı stentlerin geliştirildiği belirtilmektedir [31], [32]. Nitinol ve Ti alaşımlı malzemelerde görülen mükemmel korozif direnç, mekanik dayanımdaki yükseklik ve malzeme hafifliği, stent tasarımında diğer metallere göre daha yaygın bir kullanım alanı bulmalarını sağlamıştır [33]. CoCr alaşımı ve 316L malzemeden üretilen stentlerin yoğunluğunun Ti alaşımı olanlara göre daha yüksek olması, bu stentlerin birim boyutunun daha ağır olmasını sağlamaktadır. Ancak Ti alaşımı stentlerin işlemesi ise diğer stentlere göre daha yüksek maliyet ile sağlanabilmektedir.

Bütün stent tasarımlarında uzun süreli kullanımda ortaya çıkan ortak bir problem vardır. Vücut sıvıları ve dokularının stent malzemesi ile etkileşimi sonucunda stent yüzeyinde zaman içerisinde madde tutunumu artmakta veya stent çevresinde yeni hücrelerin oluşumu ve birikimi meydana gelmektedir. Neticede bu etkileşim; tıkanıklığı stent kullanılarak tedavi edilen bir damar yolunda, ilerleyen zamanlarda "restenoz" olarak adlandırılan tekrar tıkanma problemini meydana getirmektedir. Bu durum ayrıca kanın damar içerisindeki akış hızını ve damar çeperine yaptığı basıncı da etkileyerek düzensiz yol almasına yol açmaktadır. Kaplamasız metalik stent ve damarlar arasındaki etkileşim nedeniyle, implantasyondan sonra hastaların yaklaşık \%20-30'unda, ilk 6 ayda stent uygulanan yerde ateroskleroz veya restenoz gibi nedenlerle yeniden daralma durumu meydana gelmektedir [34], [35].

Stent yüzeyinde oluşan geç dönem tıkanma durumu temelde vücut sıvıları içerisinde bulunan parçacıkların ve hücrelerin stent malzemesine bağlanarak tutunması neticesinde meydana gelmektedir [36]. Maddelerin malzemelerin yüzeyine tutunabilmesi veya üzerinden kayıp gitmesi, aralarındaki kimyasal bağ yapma potansiyeli ile ilişkilidir. Vücut sıvısı ile stent arasındaki bağlanmanın engellenmesi durumunda, iki yüzey arasındaki kalıcı tutunmanın önüne geçileceği için geç dönem tıkanma gibi bir durum oluşamayacaktır. Hidrofobik yapıdaki bir malzemenin yüzeyine su molekülleri tutunamaz. Omnifobik malzemelere ise hiçbir madde tutunamaz. Bu bilgiler ışı̆̆ında, stentlere omnifobik davranış kazandırılması sayesinde, stent ile vücut sıvılarının etkileşimi sonucunda zamanla meydana gelen tromboz ve ateroskleroz kaynaklı damar tıkanıklığı riskinin önüne geçilebilecektir [37]-[39].

Farklı endüstriyel ve günlük ihtiyaçlara bağlı olarak, ürünlerin kullanım ömrünün uzaması amacıyla yüzey modifikasyonu veya kaplama uygulamaları sayesinde hidrofobik ve omnifobik yapılardan yararlanılmaktadır. Vücut içerisinde kalıcı bir şekilde kullanılan biyomedikal ekipmanlarda ise son yıllarda buna yönelik araştırmaların arttığı görülmektedir. Stent malzemelerine uygulanacak yüzey modifikasyonu sayesinde omnifobik özellik kazandırılabilir ve bu sayede üzerine ilaç emdirilmeden vücut sıvıları ile etkileşime girme potansiyeli azaltılabilir. Böylece; stent yüzeyindeki madde tutunumu engellenerek, geç dönem tromboz ve ateroskleroz sonucu oluşan damar tıkanıklığı riski azaltılacaktır [40]. Bu sayede, damar tıkanıklığı teşhisi konulan ve stent uygulanan hastalarda; damarın yeniden tıkanması sonucu ikinci bir cerrahi müdahaleye maruz kalınmayacağı öngörülmektedir.

Stent teknolojilerinin durumu hakkında literatürde yer alan çalışmalar, stent malzemelerinin ve yapısının geliştirilerek daha dayanıklı ve probleme kalıcı çözüm sunabilen ürünlerin elde edilmesine yönelik olduğu görülmektedir.

O’Brien ve Carroll; klinik ihtiyaçlara bağlı olarak kardiyovasküler stent malzemeleri ve yüzeylerinin gelişimi hakkında derleme makale yayınlamışlardır. Bu makalede; kardiyovasküler hastalıkların tedavisi amacıyla tasarlanan ve üretilen stentlerden ve bu stentlerin hastalara uygulanmasının ardından yaşanan olumsuzluklar neticesinde stent üzerinde yapılan gelişmeler ve buna bağlı olarak ortaya çıkan yeni ürünler incelenmiştir. Bunun için stent üretiminde kullanılan malzemeler, stent tasarımları ve kaplama yöntemleri derlenmiştir. Restenoz oranının azaltılması için stent kafesinin daha ince bir yapıdan üretilmesi gerektiği ortaya konulmuştur. Farklı kafes kalınlıklarında 316L, altın kaplamalı 316L, CoCr alaşımı malzemelerden ve 316L-Ta-316L malzemelerinden sandviç tasarımlı olarak üretilen farklı stentlerde karşılaşılan restenoz oranları kıyaslanmıştır. Restenoz oranının en yüksek olduğu stent tasarımı \%49,7 oranıyla kalın kafes yapılı ve altın kaplı 316L stentte olduğu, en düşük oranın da \%15 oranıyla ince kafes yap1l1 316L stentte olduğu görülmüştür. Restenoz oranının daha da düşürülmesi için karbon, titanyum-nitrit-oksit ve iridyum-oksit gibi kaplamaların yapılabileceği görülmüştür. Yine aynı amaç için, kaplamasız metal stentlere alternatif olarak ilaç salınımlı polimer kaplama malzemelerinden yararlanılarak yeni stentlerin üretilebildiği açıklanmaktadır. Ancak bu gruptaki stentlerin mukavemeti metal olanlar ile kıyaslandığında düşük seviyelerdedir [41]. 
Tibbitt ve ark.; biyomedikal uygulamalar için malzeme tasarımındaki gelişmeler hakkında bir araştırma gerçekleştirmişlerdir. Yapmış oldukları bu çalışmada, ilk üretildiği yıllarda mekanik destek görevi gören implant malzemelere; doku mühendisliği, nano teknoloji ve biyomalzeme alanındaki gelişmeler sayesinde fonksiyonel özellik kazandırılarak vücut ile daha uyumlu, aktif tedavi edici rol üstlenebilen malzemelerin üretildiği gerçeği yansıtılmıştır. Örneğin, spesifik bir uyarana duyarlı olacak şekilde tasarlanan bir ilaç salınımlı stent, sürekli olarak ilaç salınımı yapmaktansa sadece gerektiği durumlarda ilaç salınımı yapabilir hale gelmiştir. Bu sayede stent yüzeyine emdirilen ilacın daha uzun süre dayanmasının sağlandığı gibi, birim zamanda salınan ilaç miktarını azaltacağı için, ilaç içerisinde bulunan kimyasalın vücuda verdiği muhtemel zararlar da daha düşük seviyeye gerilemiş̧tir [42].

Lutter ve ark.; stent üretiminde spesifik mikroyapı tasarımının endotelizasyon ve tromboz üzerindeki etkilerini incelemişlerdir. $\mathrm{Bu}$ çalışmada, ilaç salınımlı stentlerdeki, tromboz oluşumunu engelleyen ilaç terapisinin, stent yüzeyinde oluşturulacak belirli mikro yapılar vasıtasıyla hızlandırılacağı düşünülmektedir. 2-5 $\mu \mathrm{m}$ yüksekliğinde oluşturulacak yükseltiler ve çukurcuklar, silikon tabaka üzerinde litografi yöntemleri ile stent malzemesi yüzeyinde oluşturulmuş ve ardından silikon-karpit ile kaplanmıştır. Kontrol grubu olarak da işlenmemiş silikon ve kaplamasız metal numuneler kullanılmıştır. Statik ve akış durumları altındaki insan toplardamarında endotel hücrelerinin gelişimini incelemek için aktin hücre iskeleti yeşil falloidin ile renklendirilmiştir. Yüzey trombojenikliğinin incelenmesi için, belirtilen koşullar altında bulundurulan numuneler, floresan ile konjuge edilmiş P-selektin antibadi ile görüntülenmiştir. Sonuçta ise işlenmemiş silikon numune ile kıyaslandığında $5 \mu \mathrm{m}$ uzunluğunda kübik yükseltilerin oluşturulduğu numunede endotel oluşumunun arttığı, $2 \mu \mathrm{m}$ uzunluğunda sivri yapıların oluşturulduğu numunede ve kaplamasız metal numunede ise bu olayın azaldığı görülmüştür [43].

Zhao ve Shu; magnezyum alaşımlı stent malzemelerinde bulunan magnezyum ve diğer alaşım elementlerinin endotel oluşumu üzerindeki etkilerini incelemişlerdir. Biyobozunur özellikte olan magnezyum alaşımlı malzemelerde, magnezyum vücut içerisinde çözündükçe alaşım elementleri iyonlaşarak vücutta salınmaktadır. Magnezyum alaşımlı stent malzemelerinde yaygın olarak kullanılan elementlerin farklı konsantrasyonlarının endotelizasyon üzerindeki etkileri de farklı olarak ortaya çıkmaktadır. Biyobozunur stent tasarımı ve üretiminde kullanılan alaşım elementleri konsantrasyonlarının uygun seçilmesi durumunda endotelizasyon seviyesinin azaltılabileceği ve bu bilginin de daha iyi biyobozunur stent üretimine 1 şık tutacağı ortaya konulmuş̧tur [44].

\subsection{2. İlaç Salınımlı Stentler}

Stentin yerleştirilmesinin ardından, yeniden tıkanmanın önüne geçmek için, Mg alaşımları gibi bozunur metaller ve vücutta çözünebilen biyopolimer teknolojisi kullanılarak "İlaç Salınımlı Stentler" (İSS), geliştirilmiştir [45]. İSS'de, ilaçlı biyopolimer metalik taban üzerine kaplanmıştır. Biyopolimere katılan bu ilaçlar, biyomalzemenin veya damarın etrafındaki plak oluşumunu engeller ya da geciktirir. Bu ilaçlar aynı zamanda damar duvarında hücrelerin çoğalıp tekrar daralmasını engelleyecek kimyasallar içermektedir [46]. İSS'lerdeki ilaç salınımı sürekli ve aynı oranda değildir. Ancak, kaplamasız stent gruplarında başlangıçta görülen yeniden daralma süreci, ilaçlı stent gruplarında yeterli ilaç salınımı sayesinde görülmemektedir [47]. İSS'de, stent implantasyonundan sonra ateroskleroz ve restenoz riski önemli ölçüde azaltılmıştır [48]. Şekil-2'de kaplamasız metal stent ile İSS teknolojisi şematik olarak gösterilmektedir.

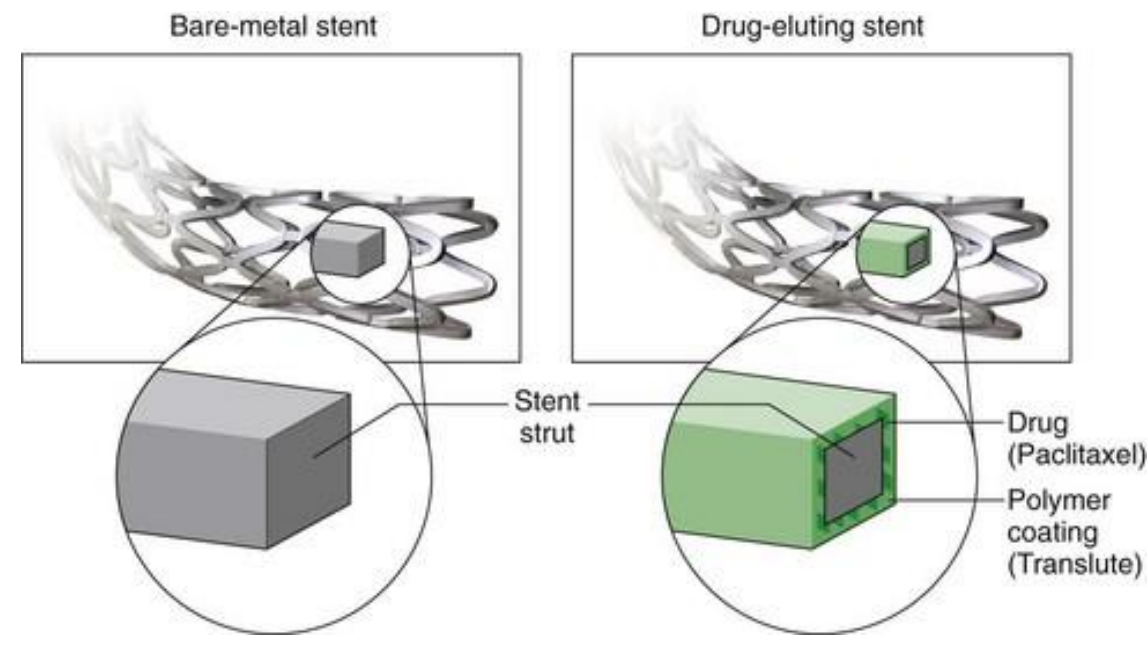

Şekil-2: Kaplamasız metal stent ve ilaç salınımlı stent

Günümüzde stent teknolojileri; stent kaynaklı restenoz problemlerinin çözülebilmesi için geliştirilmeye çalışılmaktadır. Bunun için; ilaç salınımlı stent teknolojisi geliştirilmiştir. İlaç salınımlı stentler, etraflarına yayılan maddenin kimyasal yapısı sayesinde stentin yüzeyde madde tutunumunu ve hücre birikimini azaltmaktadır. Bu tip stentler; "ilaç salınım döneminde" yeniden tıkanma riskini azaltmış olsa da, "ilaç salınımı bittikten sonra" ilaçsız stent grupları ile aynı özelliğe dönüşmekte ve daha yüksek riskte yeniden tıkanmaya sebep olmaktadırlar. Bu nedenle ilaç salınımlı stentler de restenoz problemine kalıcı bir çözüm sunamamaktadır [49]. Dolayısıyla yeni çalışmalar, kaplamasız metal stentlerin yüzey kaplaması ve modifikasyonu ile restenoz riskini düşüren yapıların elde edilmesine yöneliktir. Şekil-3'te verilen grafik son yıllardaki ve önümüzdeki 5 y1l boyunca tahmini olarak stent yüzey modifikasyonu uygulaması türüne göre ayrılan bütçenin dağılımını göstermektedir. Bu grafiğe göre önümüzdeki yıllarda yüzey 
modifikasyonu uygulamalarının ağılıklı olarak yüzeyde mikro yapıların oluşturulması yönünde artış göstereceği öngörülmektedir [50].

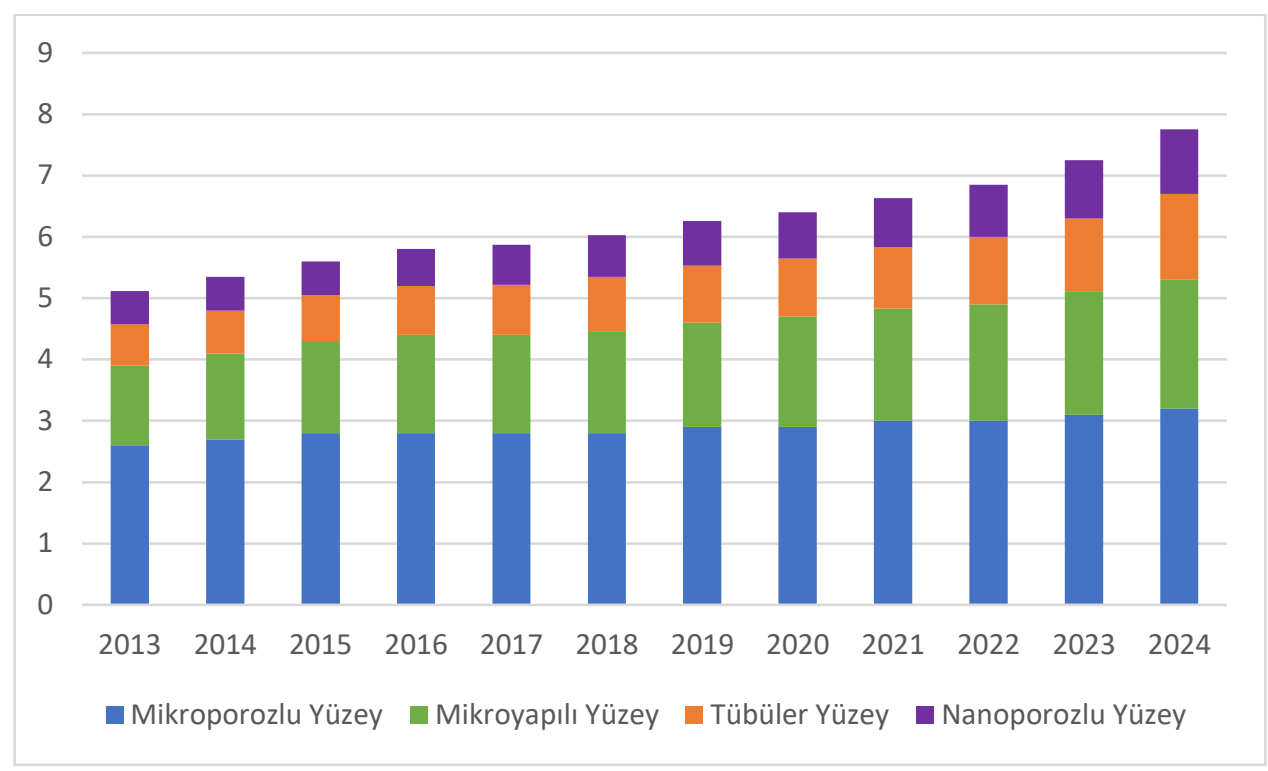

Şekil-3: Yüzey modifikasyonu türlerine ayrılan ar-ge bütçesinin geçmişte gerçekleşen ve gelecekte olması beklenen dağılımı [50]

İlaçlı stentler kaplamasız stentlere göre avantajlı olarak görülse de birçok dezavantajları da mevcuttur. İlaç kaplı stentler uzun vadede daralma riski bakımından kaplamasız stentlere göre üstünlük taşımasına stent kullanan hastalara verilen kan sulandırıcı ilaçların kullanımındaki basit bir aksamada ani tıkanma riski taşımaktadır. İSS implantasyonundan sonra oluşan trombozdan dolayı, stentin yerinden oynaması, damarın endotel tabakasının fonksiyonunun bozulması ve enfeksiyon gibi etkiler ortaya çımaktadır [51].

İSS takılmış olan bir hasta, Klopidogrel benzeri kan sulandırıcı ilaçlara (Plavix, Pingel, Karum, Effient, Brilinta, vs.) uzun süre devam etmek zorundadır. Son araştırmalar bu ilaçların en az 1 yıl kullanılması, hatta yeniden daralma yönünde yüksek riskli işlemler yapılmış ise 2-3 yıla kadar sürdürülmesi gerektiğini ortaya koymuştur. İlaç kaplı stentlerin damara temas eden dış yüzeyleri, genellikle damar endotel tabakası ile hızlı bir şekilde kapatılamadığından, kan sulandırıcı ilaçların kullanımındaki en basit bir aksama durumunda damarın pıhtı nedeniyle aniden tıkanmasına yol açabilmektedir [52]. Damar yolunun stent yüzeyine tutunan kan pıhtısından ötürü aniden tıkanması şeklinde yaşanan bu süreç son derece tehlikeli olup, birçok zaman ölümle sonuçlanmaktadır. Buna karşın, kaplamasız metalik stent takılmış olan hastalarda, stentin metal yüzeyi vücut tarafından kısa zamanda doğal endotel tabakası ile kaplanmakta, bu nedenle kan sulandırıcı ilaçların sadece birkaç ay kullanılması yeterli olmaktadır [53].

İSS takılmış olan hastalarda ilaç kullanımındaki tek sorun bu ilacın temin edilmesi ve kullanımı değil, ilacın aksatılmadan kullanımı zorunluluğudur. Herhangi bir ameliyat, diş çekimi gibi gerekçeler ile kan sulandırıcı ilaçlara kısa bir süre için de olsa ara verilmesi gerektiğinde, özellikle ilaç kaplı stent takılan hastalarda son derece vahim sonuçlar ortaya çıkabilmektedir. Kaplamasız stentlerde bu ilaçları bırakmanın çok tehlikeli olacağı dönem ilk 4 hafta olarak belirtilmektedir. Dolayısı ile ilaç kaplı stent takılması düşünülen hastalarda, en az ilk 6 ay boyunca bir cerrahi işlem ihtimalinin bulunmaması gereklidir. Yine aynı sebepten, yakın vadede kanama riski yüksek olarak değerlendirilen hastalarda da ilaç kaplı stent kullanımı sakıncalı görülmektedir. Kan sulandırıcı ilaç tedavisi kesildiğinde, stentin tıkanmasını engelleyecek başka bir çözüm mevcut değildir [54].

Vücuda yerleştirildikten sonra kalıcı olarak bulunan kaplamasız metal stentlerde ve İSS teknolojisi ürünlerinde karşılaşılan restenoz probleminin çözümü için geçici stent grupları üzerine araştırmalar yaygınlaştırılmıştır. Biyobozunur stentler olarak adlandırılan yeni bir stent grubu ortaya çıkmıştır.

\subsubsection{Biyobozunur Stentler}

Poli-Glikolik asit (PGA), Poli-Laktik asit (PLA), Poli-Üretan (PU), Poli-Karbonat (PC) ve Poli-Amid (PA) gibi polimerler ile Mg metali vücut ortamında zamanla çözünerek boşaltım sistemi aracıllğı ile vücuttan atılma özelliğine sahiptirler. Bu malzemeler biyouyumluluk açısından sorun teşkil etmemekle birlikte biyobozunur malzemeler olarak adlandırılmaktadır [55].

Biyobozunur malzemeler doğadan elde edilebildiği gibi sentetik olarak da üretilebilirler. Kitin oluşan kitosan, selüloz, fibrin, dekstran ve nişasta doğada bulunan biyobozunur polimerlerdendir [56]. Sentetik olarak üretilen biyobozunur polimerlerin kimyasal yapısının gösterimi Şekil-4’te verilmiştir. 


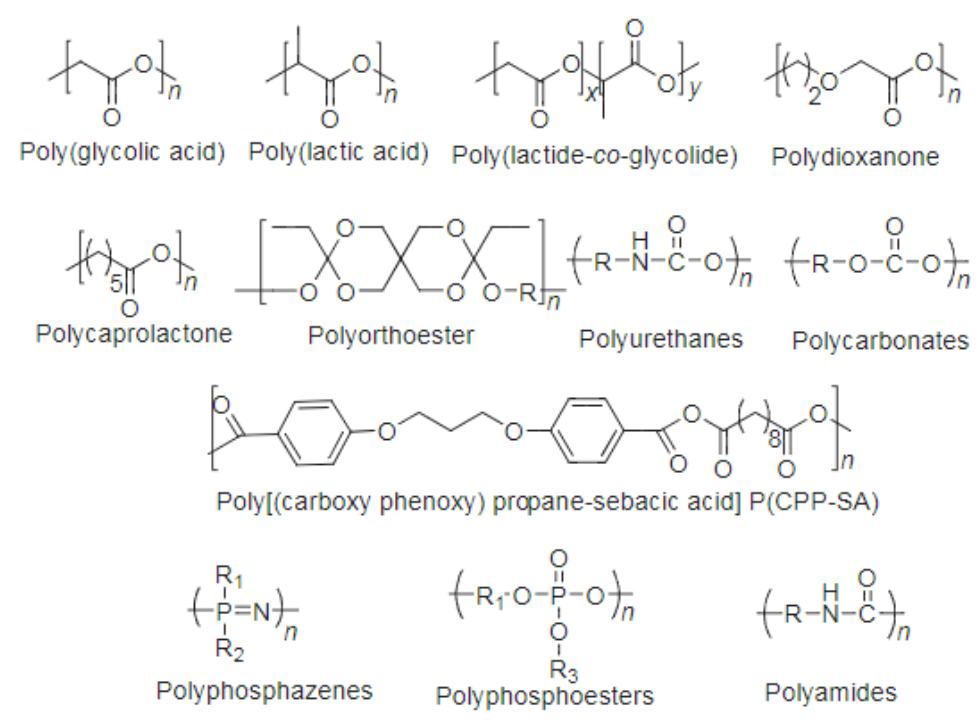

Şekil-4: Yaygın olarak kullanılan sentetik biyobozunur polimerler [56]

Stent tasarımında biyobozunur malzemeler kullanılarak üretilen ve vücutta zamanla tamamen çözünebilme kabiliyetine sahip stentlerde, kaplamasız kalıcı metal veya polimer türlerde karşılaşılan problemlerin önlenebileceği görülmüştür [57]. Biyobozunur stentler, takıldıkları damarda birkaç ayda erimeye başlayıp kaybolan ve diğer gruptaki stentler gibi geride bir kalıntı bırakmayan stentlerdir. Üretildikleri malzeme bakımından birkaç aylık bir süreçte erimeye başlayıp yok olabilme özelliği, mevcut kullanımdaki diğer stentlere göre pek çok avantaj sağlamaktadır [58].

Biyobozunur stentlerdeki bu özellik, diğer stentlerde görülen geç dönem tıkanma risklerine de neden olmadıkları görülmektedir. $\mathrm{Bu}$ olumlu özellik nedeniyle, stent yan damar ağızlarını tıkamaz ve takıldıkları damar bölgesinin vücudun o esnadaki ihtiyacına göre genişleyip büzülmesine izin verirler [59]. Tomografi ve MR cihazlarıyla görüntülemeye herhangi bir engel oluşturmazlar. Geride metal bir iskelet bırakmadıkları için aynı noktaya daha sonra yapılacak bir bypass ameliyatı için herhangi bir engel oluşturmazlar [60].

Ancak biyobozunur stentlerin; hedef damarın tedavisi tamamlanmadan önce bozunma riski, çözüm aranan bir problemdir [61]. Şekil-5'te gösterildiği gibi, bu stentlerin kalın örgülü yapıdadır. Biyobozunur stentlerin damar duvarına tutunması için uygulaması gereken dışa doğru olan kuvvet ve dirençleri henüz metal stentler kadar iyi değildir. Dolayısıyla, oldukça karmaşık ve uzun darlıkların olduğu bölgelere eriyebilir yapıdaki stentlerin takılması uygun görülmemektedir. Çünkü bu durum, hastayı ani pıhtı tıkanması ve kalp krizi riskiyle karşı karşıya bırakabilmektedir [62].

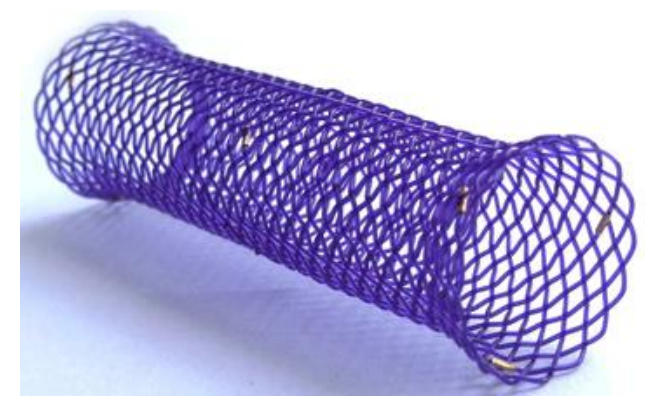

Şekil-5: Biyobozunur stent

Eriyebilir stentlerin kalın örgüleri nedeniyle esneklikleri az ve ilerletilirken damardaki kıvrıntı ve engellere takılma olasılıkları da fazladır. Bu yüzden ince ve kıvrıntılı damarlarda ilerletilmeye müsait değillerdir [63].

Eriyebilir stentlerin; takıldıkları yerdeki iltihabi tepkinin ve buna bağlı yeniden daralma riskinin azalması için ideal şartlarda 1218 ay gibi bir süre sonra tamamen eriyip kaybolmaları beklenmektedir. Bu da eriyen stentlerin pek çoğu için bu hedefe henüz erişilebilmiş değildir. Birkaç yıl önce uygulamaya ilk başlanıldığında, eriyebilme özellikleri sayesinde geç dönem tıkanma riski olmayacağı için kan sulandırıcı ilaçların da erken bırakılabileceği düşünülmekteydi. Ancak durumun pek de beklendiği gibi gelişmediği; geçen 2-3 yıl sonunda elde edilen geri bildirimlerle anlaşılmıştır [64]-[66]. Bu sebeplerle, eriyebilen stentler Avrupa'da rutin klinik kullanım için henüz onay alamamış olup, $\mathrm{AB}$ ülkelerinde 2017 itibarı ile sadece klinik araştırma kapsamında kullanım için onaya sahiptirler. Dolayısıyla yaygın bir klinik uygulamaya erişilmesi için biyobozunur stent teknolojisinin geliştirilerek diğer stent grupları kadar etkili bir kullanım fonksiyonu sunabilir niteliğe erişmesi gerekmektedir.

Biyomalzeme teknolojisindeki gelişmeler sayesinde, günümüzde kullanılan tüm stent gruplarında karşılaşılan dezavantajlar ortadan kaldırılmaya çalışılmaktadır [67]-[69]. Gelecek çalışmalarda; stent malzemelerine uygulanacak yüzey modifikasyonu sayesinde stent ile vücut sıvıları arasındaki etkileşimin olumsuz sonuçlarını azaltarak damarın tekrar tıkanması, geç dönem restenoz veya ateroskleroz gibi sorunların kalııı bir şekilde önlenebileceği öngörülmektedir [70]. 


\section{Araştırma Sonuçları ve Tartışma}

\subsection{Küresel Stent Pazarının Büyüklüğü ve Geleceği}

Dünya genelinde, kalp ve damar tıkanıklığından dolayı sağlık kuruluşlarına başvuran hastalara girişimsel tedavi yöntemleri uygulanmaktadır. Bunların başında tıkalı damar yolunun stent takılarak açılması gelmektedir. Bu durum, stent teknolojilerine olan ihtiyacın dünya genelinde oldukça yaygınlaşmasını ve stent pazarının da gelişmesini sağlamıştır [71].

Küresel ölçekte stent teknolojilerindeki harcamalar 2013 yılında yaklaşık 8 Milyar Dolar olarak gerçekleşmiştir ve bu rakam 2017 yılında artarak 9.8 Milyar Dolara gelmiştir [72]. Küresel stent pazarındaki son 5 yıl içerisinde yaklaşık \%5.7’lik büyüme sayesinde 2019 yılının sonunda bu rakamın 13 Milyar Dolar'dan daha fazla olması beklenmektedir [73]. Küresel stent pazarındaki harcamaların son yıllardaki grafiksel gösterimi Şekil-6'da verilmektedir.

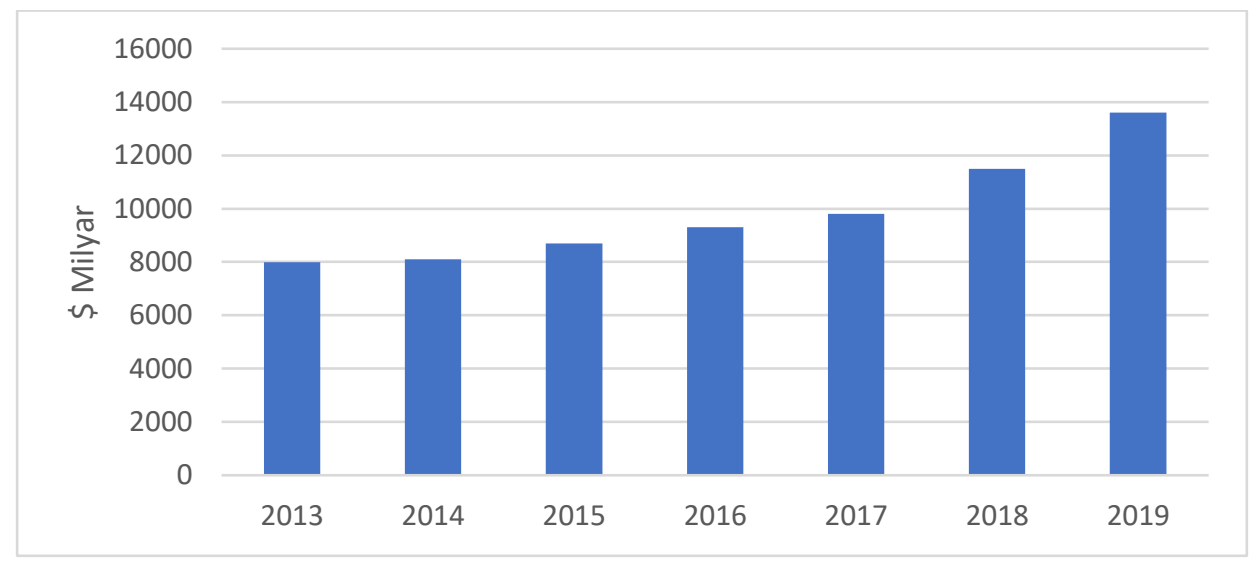

Şekil-6: Küresel stent pazarına yapılan harcamaların yıllara göre dă̆ılımı [18]

İhtiyaç duyulan duruma göre kullanım alanı bulan; kaplamasız metal stentler, ilaç salınımlı stentler ve biyobozunur stentler olmak üzere üç stent teknolojisi bulunmaktadır. Önceleri kaplamasız metal stentlerin kullanımı daha yaygın durumda iken, stent tasarımında kimyasal ajanların ve gaz enjeksiyon sistemlerindeki kullanımının yaygınlaşması sayesinde 2016 yılında İSS için yapılan harcamaların yaklaşık \%49 gibi bir rakam ile diğer teknolojilere göre daha geniş bir yer bulmuştur [74]. Küresel stent pazarındaki bu teknolojilere yapılan harcamaların dağılımı ise Şekil-7'de gösterilmektedir.

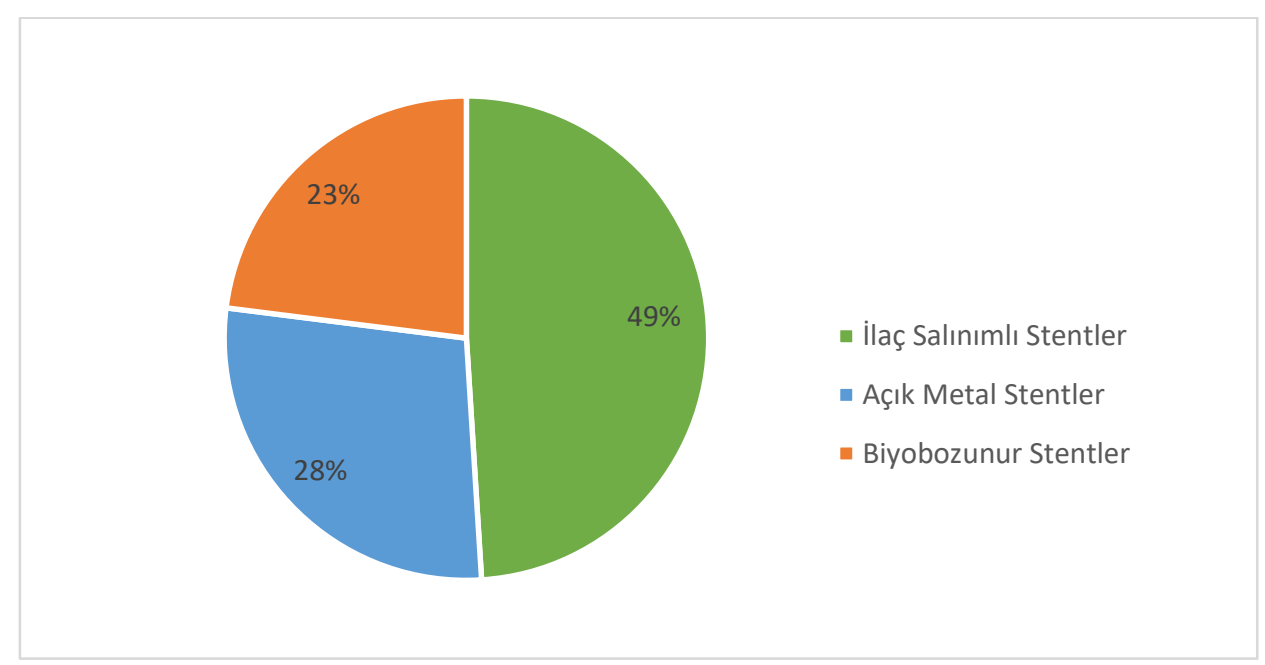

Şekil-7: Stent teknolojilerinin küresel pazardaki payları [72]

Son yıllarda biyobozunur malzeme teknolojilerine olan ilginin artmasıyla, biyobozunur stent teknolojilerinin araştırılmasına ve geliştirilmesine yapılan harcamaların daha da artarak baskın hale gelmesini sağlamıştır [75]. Stent teknolojileri pazarına ayrılan bütçenin günümüzdeki durumu ve gelecek 5 yıl içerisindeki tahmini harcama dağılımı Şekil-8'te gösterilmektedir. Bu grafiğe göre stent teknolojilerine yapılan harcamaların biyobozunur stentler yönünde artacağı ve kaplamasız metal stentlerin daha geri planda kalacağı öngörülmektedir [76]. 


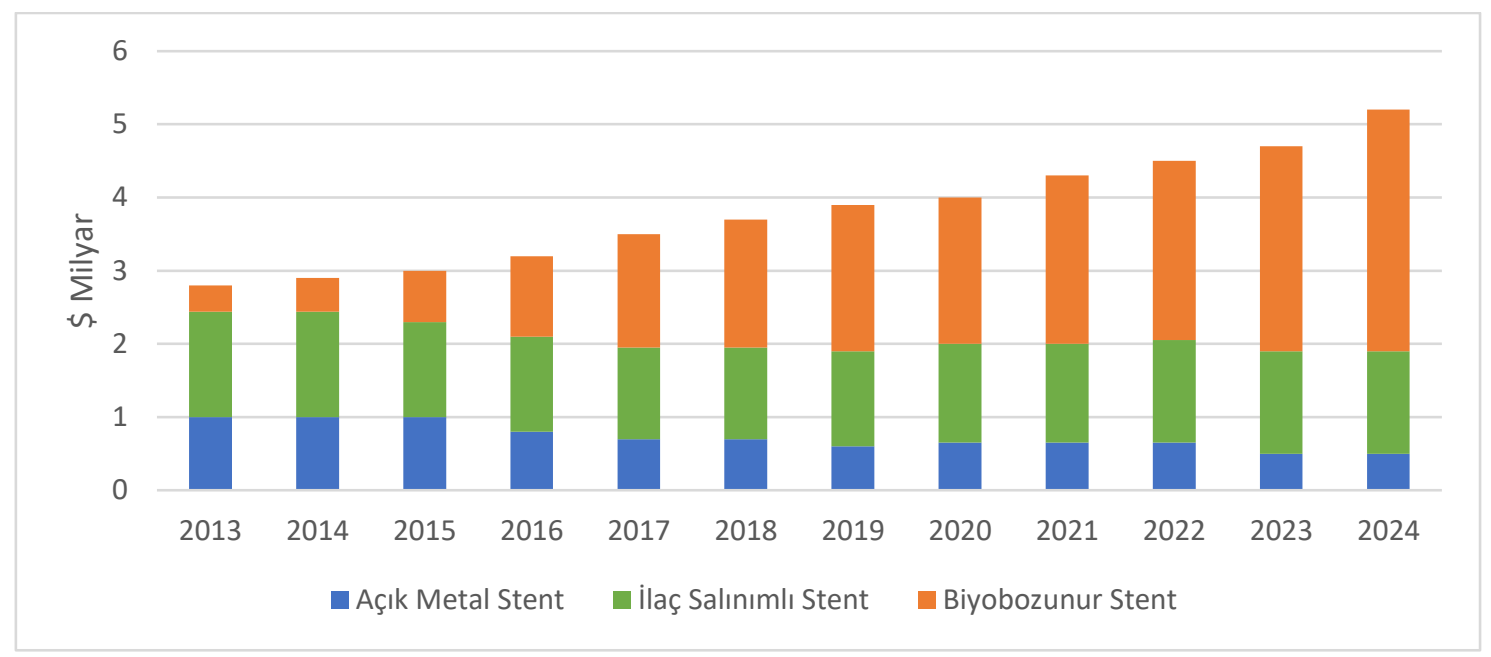

Şekil-8: Günümüze kadarki ve önümüzdeki 5 yll içerisindeki stent teknolojilerinde gerçekleşen ve beklenen harcamalartn dă̆llımı [75]

Stent pazarındaki öncü firmaların başını Almanya, Japonya, Çin, A.B.D. ve Hindistan çekmektedir. Gelecek dönemde küresel stent pazarının \%7.8 büyümesi beklenmektedir. Bu büyümeyi gerçekleştirecek olan öncü firmalar şu şekilde sıralanabilir [77], [78]:

- BIOTRONIK SE \& Co. KG (Almanya)

- Terumo Corporation (Japonya)

- $\quad$ MicroPort Scientific Corporation (Çin)

- Abbott Laboratories (A.B.D.)

- Meril Life Science (Hindistan)

Verilen grafiklerden de anlaşılacağı üzere, gelecek yıllarda yapılacak çalışmalar, stent teknolojilerinde yararlanılan farklı tasarımlarda meydana gelen restenoz gibi problemlere çözüm sunması açısından şekillenmektedir. Bu bakımdan yeni tasarımlara olan ihtiyaçların da artan bir hızla devam ettiği görülmektedir. Her ne kadar biyobozunur ve ilaç salınımlı stentlere ayrılması beklenen bütçenin daha da fazla olacă̆ı öngörülse de, kaplamasız metal stentlerin geliştirilmesine yönelik çalışmalar da devam ettirilmektedir. $\mathrm{Bu}$ kapsamda ortaya konulan AR-GE çalışmaları, stent içi restenoz problemine kalıcı bir çözümün sağlaması amacıyla şekillendirilmektedir.

\section{Sonuç}

Klinik uygulamalarda, damar tıkanıklı̆ı̆ tedavisinde kullanılan damar içi stentler hayat kurtarıcı bir rol üstlenmektedir. Geçmişten günümüze kadar üretilen ve kullanılan stentlerin üretim malzemesi ve stent tasarımları sürekli olarak çeșitlilik göstermiştir. Kaplamasız metal stentler halen yaygın bir şekilde kullanılıyor olsa da, bu stent grubunda karşılaşılan yüksek oranlı restenoz problemi nedeniyle İSS teknolojisi bu stent grubunun yerini almaya başlamışıtır. Ancak İSS teknolojisi bu problem ile karşılaşma riskini düşürmüş olsa da, kalıcı olarak çözüm sağlayamamıştır. Vücutta kalıcı olarak bulunan bu iki stent grubunda da ilerleyen zamanlarda damarın yeniden tıkanması olasılığı bulunmaktadır. Kalıcı stentlerde karşılaşılan komplikasyonların ve restenozun önüne geçilmesi için geliştirilen biyobozunur stentlerde ise AR-GE faaliyetleri halen devam etmekte olup, bu teknoloji ile üretilen stentler diğer iki stent grubu kadar henüz yaygın bir klinik kullanım alanı bulamamıştır. Bu nedenlerle stent teknolojisi sürekli olarak geliştirilmeye devam etmektedir. Bunun için biyomalzeme teknolojilerine ve stentlere ayrılan bütçe azımsanmayacak kadar çoktur. Gelecek çalışmalar, özellikle stent malzemesinin yapısal özelliğinden kaynaklanan komplikasyonların daha da azaltılması, hatta tamamen çözülmesine yönelik olarak kurgulanmaktadır.

Biyomalzemelere uygulanacak yüzey modifikasyonu sayesinde insan sağlığına daha elverişli hale gelmesi sağlanarak bu problemlerin yakın gelecekte tamamen çözülebileceği tahmin edilmektedir. Bunun için endüstriyel uygulamalarda da yararlanılan hidrofobik ve omnifobik yüzey yapılarının damar içi stent üzerinde biyouyumlu malzemelerden yararlanılarak oluşturulması, yüzeyde madde tutmama fonksiyonu kazandırma açısından katkı sunacaktır. Dolayısısyla, günümüzde kullanılan mevcut stentlerde karşılaşılan stent içi restenoz probleminin kalıcı olarak çözüleceği öngörülmektedir.

\section{Teşekkür}

Bu çalışma Erciyes Üniversitesi Bilimsel Araştırma Projeleri Koordinasyon Birimi tarafından FDK-2019-8754 numaralı proje ile desteklenmektedir. 


\section{Kaynakça}

1. N. Sarwar et al., Emerging Risk Factors Collaboration. (2010). Diabetes mellitus, fasting blood glucose concentration, and risk of vascular disease: a collaborative meta-analysis of 102 prospective studies. The Lancet, 375(9733), 2215-2222.

2. Cutlip, D. E., Windecker, S., Mehran, R., Boam, A., Cohen, D. J., van Es, G. A., et. al. (2007). Clinical end points in coronary stent trials: a case for standardized definitions. Circulation, 115(17), 2344-2351.

3. Sanchez, O. D., Sakakura, K., Otsuka, F., Yahagi, K., Virmani, R., \& Joner, M. (2014) Coronary stent evolution-from pathology to clinic. EMJ Int. Cardiol., 107-116.

4. Halwani, D. O., Anderson, P. G., Lemons, J. E., Jordan, W. D., Anayiotos, A. S., \& Brott, B. C. (2010). In-vivo corrosion and local release of metallic ions from vascular stents into surrounding tissue. Journal of Invasive Cardiology, 22(11), 528-535.

5. Iqbal, J., Gunn, J., \& Serruys, P. W. (2013). Coronary stents: historical development, current status and future directions. British medical bulletin, 106(1), 193-211.

6. Huang, Q., Yang, Y., Hu, R., Lin, C., Sun, L., \& Vogler, E. A. (2015). Reduced platelet adhesion and improved corrosion resistance of superhydrophobic TiO2-nanotube-coated 316L stainless steel. Colloids and Surfaces B: Biointerfaces, $125,134-141$.

7. Lange, D., Bidnur, S., Hoag, N., \& Chew, B. H. (2015). Ureteral stent-associated complications-where we are and where we are going. Nature Reviews Urology, 12(1), 17-25.

8. Lin, Q., Ding, X., Qiu, F., Song, X., Fu, G., \& Ji, J. (2010). In situ endothelialization of intravascular stents coated with an antiCD34 antibody functionalized heparin-collagen multilayer. Biomaterials, 31(14), 4017-4025.

9. Balossino, R., Gervaso, F., Migliavacca, F., \& Dubini, G. (2008). Effects of different stent designs on local hemodynamics in stented arteries. Journal of biomechanics, 41(5), 1053-1061.

10. Hamilos, M. I., Ostojic, M., Beleslin, B., Sagic, D., Mangovski, L., Stojkovic, S., et. al. (2008). Differential effects of drugeluting stents on local endothelium-dependent coronary vasomotion. Journal of the American College of Cardiology, 51(22), 2123-2129.

11. Bhatt, D. L. (2012). EXAMINATION of new drug-eluting stents-top of the class!. The Lancet, 380(9852), $1453-1455$.

12. Alfonso, F., Byrne, R. A., Rivero, F., \& Kastrati, A. (2014). Current treatment of in-stent restenosis. Journal of the American College of Cardiology, 63(24), 2659-2673.

13. Hermawan, H., Dubé, D., \& Mantovani, D. (2010). Developments in metallic biodegradable stents. Acta biomaterialia, 6(5), 1693-1697.

14. Moravej, M., \& Mantovani, D. (2011). Biodegradable metals for cardiovascular stent application: interests and new opportunities. International journal of molecular sciences, 12(7), 4250-4270.

15. Bangalore, S., Toklu, B., Amoroso, N., Fusaro, M., Kumar, S., Hannan, E. L., et. al. (2013). Bare metal stents, durable polymer drug eluting stents, and biodegradable polymer drug eluting stents for coronary artery disease: mixed treatment comparison metaanalysis. Bmj, 347, 1-20.

16. Schillinger, M., Sabeti, S., Loewe, C., Dick, P., Amighi, J., Mlekusch, W., et. al. (2006). Balloon angioplasty versus implantation of nitinol stents in the superficial femoral artery. New England Journal of Medicine, 354(18), 1879-1888.

17. Lee, S. W., Park, S. W., Kim, Y. H., Yun, S. C., Park, D. W., Lee, C. W., et. al. (2011). A randomized, double-blind, multicenter comparison study of triple antiplatelet therapy with dual antiplatelet therapy to reduce restenosis after drug-eluting stent implantation in long coronary lesions: results from the DECLARE-LONG II (Drug-Eluting Stenting Followed by Cilostazol Treatment Reduces Late Restenosis in Patients with Long Coronary Lesions) trial. Journal of the American College of Cardiology, 57(11), 1264-1270.

18. Praveen Kumar, G., Jafary-Zadeh, M., Tavakoli, R., \& Cui, F. (2017). Feasibility of using bulk metallic glass for self-expandable stent applications. Journal of Biomedical Materials Research Part B: Applied Biomaterials, 105(7), 1874-1882.

19. Amanov, A., Lee, S. W., \& Pyun, Y. S. (2017). Low friction and high strength of $316 \mathrm{~L}$ stainless steel tubing for biomedical applications. Materials Science and Engineering: C, 71, 176-185.

20. Siontis, G. C., Stefanini, G. G., Mavridis, D., Siontis, K. C., Alfonso, F., Pérez-Vizcayno, M. J., et. al. (2015). Percutaneous coronary interventional strategies for treatment of in-stent restenosis: a network meta-analysis. The Lancet, 386(9994), 655-664.

21. Palmerini, T., Benedetto, U., Biondi-Zoccai, G., Della Riva, D., Bacchi-Reggiani, L., Smits, P. C., et. al. (2015). Long-term safety of drug-eluting and bare-metal stents: evidence from a comprehensive network meta-analysis. Journal of the American College of Cardiology, 65(23), 2496-2507.

22. Bandar, A. M., Rosaire, M., \& Stephen, Y. (2013). Coronary stents fracture: an engineering approach. Materials Sciences and Applications, 4(10), 606-621.

23. Menown, I. B., Noad, R., Garcia, E. J., \& Meredith, I. (2010). The platinum chromium element stent platform: from alloy, to design, to clinical practice. Advances in therapy, 27(3), 129-141.

24. Chao, Z., Yaomu, X., Chufeng, L., \& Conghua, L. (2017). The effect of mucin, fibrinogen and IgG on the corrosion behaviour of $\mathrm{Ni}-\mathrm{Ti}$ alloy and stainless steel. Biometals, 30(3), 367-377.

25. O’Brien, B., Zafar, H., Ibrahim, A., Zafar, J., \& Sharif, F. (2016). Coronary stent materials and coatings: a technology and performance update. Annals of biomedical engineering, 44(2), 523-535.

26. Weiss, S., \& Mitevski, B. (2015). Microstructure and deformation of coronary stents from cocr-alloys with different designs. Materials, 8(5), 2467-2479.

27. Hanawa, T. (2012). Research and development of metals for medical devices based on clinical needs. Science and technology of advanced materials, 13(6), 064102.

28. Niinomi, M., Nakai, M., \& Hieda, J. (2012). Development of new metallic alloys for biomedical applications. Acta biomaterialia, 8(11), 3888-3903. 
29. Kraus, T., Moszner, F., Fischerauer, S., Fiedler, M., Martinelli, E., Eichler, J., et. al. (2014). Biodegradable Fe-based alloys for use in osteosynthesis: Outcome of an in vivo study after 52 weeks. Acta biomaterialia, 10(7), 3346-3353.

30. Schinhammer, M., Gerber, I., Hänzi, A. C., \& Uggowitzer, P. J. (2013). On the cytocompatibility of biodegradable Fe-based alloys. Materials Science and Engineering: C, 33(2), 782-789.

31. Grogan, J. A., Leen, S. B., \& McHugh, P. E. (2012). Comparing coronary stent material performance on a common geometric platform through simulated bench testing. Journal of the mechanical behavior of biomedical materials, 12, 129-138.

32. Pinedo, M. A. (2016). Investigation of the Corrosion Behaviour of Bare and Polypyrrole-coated WE43 Magnesium Alloy for the Development of Biodegradable Implants. Doctoral dissertation, McGill University Libraries.

33. Azaouzi, M., Makradi, A., \& Belouettar, S. (2012). Deployment of a self-expanding stent inside an artery: a finite element analysis. Materials \& Design, 41, 410-420.

34. Siontis, G. C., Stefanini, G. G., Mavridis, D., Siontis, K. C., Alfonso, F., Pérez-Vizcayno, M. J., et. al. (2015). Percutaneous coronary interventional strategies for treatment of in-stent restenosis: a network meta-analysis. The Lancet, 386(9994), 655-664.

35. Zhou, Z., Yin, Q., Xu, G., Yue, X., Zhang, R., Zhu, W., et. al. (2011). Influence of vessel size and tortuosity on in-stent restenosis after stent implantation in the vertebral artery ostium. Cardiovascular and interventional radiology, 34(3), 481-487.

36. Guo, Z., Zhou, F., Hao, J., \& Liu, W. (2005). Stable biomimetic super-hydrophobic engineering materials. Journal of the American Chemical Society, 127(45), 15670-15671.

37. Callies, M., Chen, Y., Marty, F., Pépin, A., \& Quéré, D. (2005). Microfabricated textured surfaces for super-hydrophobicity investigations. Microelectronic engineering, 78, 100-105.

38. Hsieh, C. T., Chen, J. M., Kuo, R. R., Lin, T. S., \& Wu, C. F. (2005). Influence of surface roughness on water-and oil-repellent surfaces coated with nanoparticles. Applied Surface Science, 240(1-4), 318-326.

39. Horgnies, M., \& Chen, J. J. (2014). Superhydrophobic concrete surfaces with integrated microtexture. Cement and Concrete Composites, 52, 81-90.

40. Rao, A. P., \& Rao, A. V. (2010). Modifying the surface energy and hydrophobicity of the low-density silica aerogels through the use of combinations of surface-modification agents. Journal of materials science, 45(1), 51-63.

41. O’Brien, B., \& Carroll, W. (2009). The evolution of cardiovascular stent materials and surfaces in response to clinical drivers: a review. Acta biomaterialia, 5(4), 945-958.

42. Tibbitt, M. W., Rodell, C. B., Burdick, J. A., \& Anseth, K. S. (2015). Progress in material design for biomedical applications. Proceedings of the National Academy of Sciences, 112(47), 14444-14451.

43. Lutter, C., Nothhaft, M., Rzany, A., Garlichs, C. D., \& Cicha, I. (2015). Effect of specific surface microstructures on substrate endothelialisation and thrombogenicity: Importance for stent design. Clinical hemorheology and microcirculation, 59(3), 219233.

44. Zhao, N., \& Zhu, D. (2015). Endothelial responses of magnesium and other alloying elements in magnesium-based stent materials. Metallomics, 7(1), 118-128.

45. Chen, Y., Xu, Z., Smith, C., \& Sankar, J. (2014). Recent advances on the development of magnesium alloys for biodegradable implants. Acta biomaterialia, 10(11), 4561-4573.

46. Puskas, J. E., Muñoz-Robledo, L. G., Hoerr, R. A., Foley, J., Schmidt, S. P., Evancho-Chapman, M., et. al. (2009). Drug-eluting stent coatings. Wiley Interdisciplinary Reviews: Nanomedicine and Nanobiotechnology, 1(4), 451-462.

47. Alfonso, F., Pérez-Vizcayno, M. J., Cárdenas, A., del Blanco, B. G., García-Touchard, A., López-Minguéz, J. R., et. al. (2015). A prospective randomized trial of drug-eluting balloons versus everolimus-eluting stents in patients with in-stent restenosis of drugeluting stents: the RIBS IV randomized clinical trial. Journal of the American College of Cardiology, 66(1), 23-33.

48. Ali, M. T., Martin, K., Kumar, A. H., Cavallin, E., Pierrou, S., Gleeson, B. M., et. al. (2015). A novel CX3CR1 antagonist eluting stent reduces stenosis by targeting inflammation. Biomaterials, 69, 22-29.

49. Azarnoush, H., \& Boulet, B. (2010, June). Angioplasty balloon deployment control. In Proceedings of the 2010 American Control Conference (pp. 3572-3573). IEEE.

50. G. V. Research, (2016). Drug Eluting Stent Market, By Polymer-based Coatings (Non-biodegradable Polymer-based, Biodegradable Polymer-based), Polymer-free Coatings (Micro Porous Surface, Microstructured Surface, Slotted Tubular Surface, Nanoporous Surface), By Application (Corona. Mark. Res. Rep. 1-89.

51. Lee, S. Y., Ahn, J. M., Mintz, G. S., Hur, S. H., Choi, S. Y., Kim, S. W., et. al. (2017). Characteristics of Earlier Versus Delayed Presentation of Very Late Drug-Eluting Stent Thrombosis: An Optical Coherence Tomographic Study. Journal of the American Heart Association, 6(4), e005386.

52. Av, F., Joner, M., Nakazawa, G., Kolodgie, F., Newell, J., \& MC, J. (2007). Pathological correlates of late drug-eluting stent thrombosis. Circulation, 115, 2435-2441.

53. Sukavaneshvar, S. (2017). Device thrombosis and pre-clinical blood flow models for assessing antithrombogenic efficacy of drugdevice combinations. Advanced drug delivery reviews, 112, 24-34.

54. Montalescot, G., Brieger, D., Dalby, A. J., Park, S. J., \& Mehran, R. (2015). Duration of dual antiplatelet therapy after coronary stenting: a review of the evidence. Journal of the American College of Cardiology, 66(7), 832-847.

55. Iwata, T. (2015). Biodegradable and bio-based polymers: future prospects of eco-friendly plastics. Angewandte Chemie International Edition, 54(11), 3210-3215.

56. Doppalapudi, S., Jain, A., Khan, W., \& Domb, A. J. (2014). Biodegradable polymers - an overview. Polymers for Advanced Technologies, 25(5), 427-435.

57. Waksman, R., \& Pakala, R. (2010). Biodegradable and bioabsorbable stents. Current pharmaceutical design, 16(36), 4041-4051.

58. Zhu, Y., Yang, K., Cheng, R., Xiang, Y., Yuan, T., Cheng, Y., et. al. (2017). The current status of biodegradable stent to treat benign luminal disease. Materials Today, 20(9), 516-529. 
59. Hermawan, H., Dubé, D., \& Mantovani, D. (2010). Degradable metallic biomaterials: design and development of Fe-Mn alloys for stents. Journal of Biomedical Materials Research Part A: An Official Journal of The Society for Biomaterials, The Japanese Society for Biomaterials, and The Australian Society for Biomaterials and the Korean Society for Biomaterials, 93(1), 1-11.

60. Waksman, R., Pakala, R., Kuchulakanti, P. K., Baffour, R., Hellinga, D., Seabron, R., et. al. (2006). Safety and efficacy of bioabsorbable magnesium alloy stents in porcine coronary arteries. Catheterization and Cardiovascular Interventions, 68(4), 607617.

61. Repici, A., Pagano, N., Rando, G., Carlino, A., Vitetta, E., Ferrara, E., et. al. (2013). A retrospective analysis of early and late outcome of biodegradable stent placement in the management of refractory anastomotic colorectal strictures. Surgical endoscopy, 27(7), 2487-2491.

62. Waksman, R. (2007). Promise and challenges of bioabsorbable stents. Catheterization and Cardiovascular Interventions, 70(3), 407-414.

63. Moore, J. E., Soares, J. S., \& Rajagopal, K. R. (2010). Biodegradable stents: biomechanical modeling challenges and opportunities. Cardiovascular Engineering and Technology, 1(1), 52-65.

64. Byrne, R. A., Joner, M., \& Kastrati, A. (2015). Stent thrombosis and restenosis: what have we learned and where are we going? The Andreas Grüntzig Lecture ESC 2014. European heart journal, 36(47), 3320-3331.

65. Gomez-Blazquez, I., Diaz, V. J., Fernandez-Barbeira, S., Fernández, G. B., Castro, A. D. M., Alonso, J. A. B., et. al. (2017). TCT847 Everolimus-eluting bioresorbable scaffold for the treatment of coronary in-stent restenosis: immediate and 12 months clinical results. Journal of the American College of Cardiology, 70(18 Supplement), B342.

66. Gomez-Blazquez, I., Diaz, V. J., Fernandez-Barbeira, S., Fernández, G. B., Castro, A. D. M., Alonso, J. A. B., et. al. (2017). TCT849 In-stent restenosis treated with everolimus-eluting bioresorbable scaffold: 1-year angiographic results. Journal of the American College of Cardiology, 70(18 Supplement), B343.

67. Katz, G., Harchandani, B., \& Shah, B. (2015). Drug-eluting stents: the past, present, and future. Current atherosclerosis reports, $17(3), 11$.

68. Kolk, A., Handschel, J., Drescher, W., Rothamel, D., Kloss, F., Blessmann, M., et. al. (2012). Current trends and future perspectives of bone substitute materials-from space holders to innovative biomaterials. Journal of Cranio-Maxillofacial Surgery, 40(8), 706-718.

69. Mahnken, A. H. (2012). CT imaging of coronary stents: past, present, and future. ISRN cardiology, 1-12.

70. Diao, C. L. Y. Z. Z., \& Wang, J. Q. G. (2011). Research progress and future prospects for promoting endothelialization on endovascular stents and preventing restenosis. Journal of Medical and Biological Engineering, 31(5), 307-316.

71. Murphy, E. A., \& Boyle, F. J. (2012). Reducing in-stent restenosis through novel stent flow field augmentation. Cardiovascular Engineering and Technology, 3(4), 353-373.

72. Tan, A., Alavijeh, M. S., \& Seifalian, A. M. (2012). Next generation stent coatings: convergence of biotechnology and nanotechnology. Trends in biotechnology, 30(8), 406-409.

73. Moore, S. S., O'Sullivan, K. J., \& Verdecchia, F. (2016). Shrinking the supply chain for implantable coronary stent devices. Annals of biomedical engineering, 44(2), 497-507.

74. G. V. Research. (2018). Coronary Stent Market Size, Share \& Trend Analysis Report by Product (Bare Metal Stents, Drug Eluting Stents, Bioresorbable Vascular Scaffold), And Segment Forecasts 2018 - 2024. 1-82.

75. Im, S. H., Jung, Y., \& Kim, S. H. (2017). Current status and future direction of biodegradable metallic and polymeric vascular scaffolds for next-generation stents. Acta biomaterialia, 60, 3-22.

76. Kalra, A., Rehman, H., Khera, S., Thyagarajan, B., Bhatt, D. L., Kleiman, N. S., \& Yeh, R. W. (2017). New-generation coronary stents: current data and future directions. Current atherosclerosis reports, 19(3), 14-23.

77. Regazzoli, D., Leone, P. P., Colombo, A., \& Latib, A. (2017). New generation bioresorbable scaffold technologies: an update on novel devices and clinical results. Journal of thoracic disease, 9(Suppl 9), 979-985.

78. Foerst, J., Vorpahl, M., Engelhardt, M., Koehler, T., Tiroch, K., \& Wessely, R. (2013). Evolution of coronary stents: from baremetal stents to fully biodegradable, drug-eluting stents. Combination Products in Therapy, 3(1-2), 9-24. 